\title{
Catalyst-free, a Green, and Efficient Protocol for the Synthesis of 1,8- dioxooctahydroxanthenes in Magnetized Water
}

\author{
Mohammad Bakherad*, Ali Keivanloo, Amir Hossein Amin, Amir Farkhondeh \\ Faculty of Chemistry, Shahrood University of Technology, Shahrood 3619995161, Iran. \\ *Corresponding author: Mohammad Bakherad, e-mail: m.bakherad@yahoo.com Tel/Fax: \\ $+982332395441$
}

Received May 1 ${ }^{\text {st }}, 2019 ;$ Accepted August $4^{\text {th }}, 2019$

DOI: http://dx.doi.org/10.29356/jmcs.v63i4.865

\begin{abstract}
In this paper, we report the catalyst-free three-component synthesis of 1,8-dioxooctahydroxanthenes in magnetized water as a green solvent. The reaction of aldehydes and 1,3-cyclohexanedione/dimedone in magnetized water gives the 9-substituted 1,8-dioxooctahydroxanthene derivatives. This green method offers the advantages of short reaction times, low-cost, simple work-up procedure, quantitative reaction yields, and no need for an organic solvent.

Keywords: 1,8-dioxooctahydroxanthenes; catalyst-free; magnetized water.

Resumen. En este trabajo se describe la síntesis, sin catalizador, de 1,8-dioxooctahidroxantenos empleando agua magnetizada como disolvente ecológico. La reacción de aldehídos y 1,3-ciclohexanodiona/dimedona en agua magnetizada da lugar a derivados 9-sustituídos del 1,8-dioxooctahidroxanteno. Este método verde tiene la ventaja de tiempos cortos de reacción, bajo costo, trabajo de reacción simple, rendimientos cuantitativos y no necesita el empleo de un disolvente orgánico.
\end{abstract}

Palabras clave: 1,8-Dioxooctahidroxantenos; sin catalizador; agua magnetizada.

\section{Introduction}

Xanthenes are one of the most broadly distributed groups of natural compounds. Most xanthene derivatives have several biological activities such as the anti-inflammatory,[1] anti-viral,[2] anti-tumor,[3] and anti-cancer [4] properties. Moreover, in the field of material science, they are used as dyes,[5] $\mathrm{pH}$-sensitive fluorescent materials, [6] and photo-stable laser dyes.[7] Thus the production of different xanthene derivatives is of great significance. One of the typical methods used for the synthesis of xanthene derivatives involves the condensation of aldehydes using 5,5-dimethyl-1,3-cyclohexanedione or 1,3-cyclohexanedione in the presence of a catalyst. However, in the absence of a catalyst,[8] the reaction ends just after the Knoevenagel-type adduct formation to yield an open-chain intermediate, 2,2'-aryl/alkyl methylene-bis(3-hydroxy-5,5-dimethyl-2cyclohexene-1-one). On the other hand, the reaction of aldehydes with 1,3-cyclohexanedione or 5,5-dimethyl1,3-cyclohexanedione for the synthesis of xanthene derivatives is carried out in the presence of different

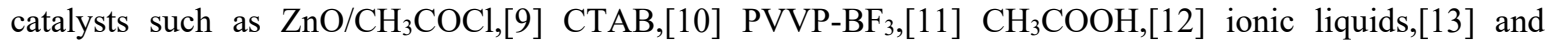
proline.[14] The value of a method for the synthesis of this significant group of heterocyclic compounds mainly depends upon identifying a cost-effective, simple, and eco-friendly catalyst, and a simple work-up procedure. The above-mentioned methods, however, show varying degrees of achievements as well as limitations such as 
low reaction yields, lengthy reaction times, harsh reaction conditions, use of toxic and costly reagents/catalysts, and complex work-up procedures. Keeping in view the drawbacks associated with the reported protocols as well as the increasing importance of xanthenes in industrial and pharmaceutical chemistry, there still remains a high request for the synthesis of efficient, more general, eco-friendly, additive, and catalyst-free protocols to assemble such scaffolds.

In a majority of catalytic processes, organic solvents are used up as the reaction solvent, frequently producing health, safety, and environmental issues due to their toxicity, flammability, and volatility. From the environmental and economic viewpoints, it is advisable to keep away from the utilization of dangerous and costly organic solvents. The utilization of water as the solvent shows valuable gains because it is very polar and thus immiscible with a majority of organic compounds. Therefore, water-soluble by-products stay and isolation of the organic materials is easy.[15]

However, most reactions could not be conducted in water as a solvent because they require the presence of bases, acids, additives or catalysts. Thus if one can change the physical properties of water, its reactivity toward organic reagents could be changed. The change in the properties of water under the action of an applied magnetic field is just a typical case. The change in the properties of water under the action of an external magnetic field is just a typical case.

From the $1950^{\circ} \mathrm{s}$, we have known that water can be magnetized in the presence of an applied magnetic field, although with a minimal effect.[16-18] On the basis of literature surveys carried out on magnetized water during the past few years, most researchers have been interested in studying the effect of an applied magnetic field on the properties of water,[19] especially the hydrogen bond distribution.[20,21] Furthermore, due to the magnetization many properties of water, such as density, penetration, specific heat, refractive index, electric dipole-moment, average cluster size in the bulk water, vaporization enthalpy, surface tension and viscosity, change compared with non-magnetic water.[22-24] In view of the above-mentioned considerations and according to our progressive endeavors in developing multi-component reactions in magnetized water,[25-29] herein we wish to report a green method for the one-pot synthesis of 1,8-dioxooctahydroxanthenes in magnetized water (Scheme 1).<smiles>[R]C1([R])CC(=O)C2=C(C1)OC1=C(C(=O)CC([R])([R])C1)C2[Al]C</smiles>

Scheme 1. Synthesis of 1,8-dioxooctahydroxanthenes in magnetized water.

\section{Experimental}

\section{General}

The reagents and solvents used were supplied from Merck, Fluka or Aldrich. Melting points were determined using an electro-thermal $\mathrm{C} 14500$ apparatus. The reaction progress and the purity of compounds were monitored using TLC analytical silica gel plates (Merck 60 F250). All the known compounds were identified by comparing their melting points and ${ }^{1} \mathrm{H}$ NMR data with those in the authentic samples. The ${ }^{1} \mathrm{H}$ NMR (300 MHz) and ${ }^{13} \mathrm{C}$ NMR (75 MHz) spectroscopies were run on a Bruker Advance DPX-250 FT-NMR spectrometer. The chemical shift values were given as $\delta$ values against tetramethylsilane as the internal standard, and the J values were given in Hz. Microanalysis was performed on a Perkin-Elmer 240-B microanalyzer. The $\mathrm{pH}$ measurements were made using a metrohm $744 \mathrm{pH}$-meter glass electrode.

\section{Preparation of magnetized water}

In order to prepare a magnetized water sample according to Fig. $1,5 \mathrm{~mL}$ distilled water was first put in a test tube, which was then put between two neodymium magnets $\mathrm{NdFeB}(10 \mathrm{~cm} \times 5 \mathrm{~cm} \times 4 \mathrm{~cm})$ with a 
magnetic field of $0.8 T$ for $20 \mathrm{~min}$. The test tube was subsequently removed from the instrument and used for the reaction.

\section{General procedure for synthesis of 1,8-dioxooctahydroxanthenes (4a-r)}

To a $10-\mathrm{mL}$ round-bottomed flask equipped with a heater and containing magnetized water $(3 \mathrm{~mL}$, $\mathrm{pH}=6.6)$ were added a 1,3 -cyclohexanedione or dimedone $(2.0 \mathrm{mmol})$ and an aldehyde $(1.0 \mathrm{mmol})$. The reaction mixture was heated at $90^{\circ} \mathrm{C}$ and monitored by the thin layer chromatography (TLC) technique. After completion of the reaction, the precipitate thus formed was filtered and subsequently washed with ethanol to afford the desired product (Table 4).

\section{3,4,6,7-Tetrahydro-9-phenyl-2H-xanthene-1,8(5H,9H)-dione (4a)}

White solid; mp 202-204 ${ }^{\circ} \mathrm{C} ;{ }^{1} \mathrm{H}$ NMR (DMSO- $\left.d_{6}, 300 \mathrm{MHz}\right) \delta 1.99-2.18\left(\mathrm{~m}, 4 \mathrm{H}, \mathrm{CH}_{2}\right), 2.20-2.35(\mathrm{~m}$, 4H, $\left.\mathrm{CH}_{2}\right), 2.47-2.62\left(\mathrm{~m}, 4 \mathrm{H}, \mathrm{CH}_{2}\right), 5.22(\mathrm{~s}, 1 \mathrm{H}, \mathrm{CH}), 7.00-7.15(\mathrm{~m}, 3 \mathrm{H}, \mathrm{ArH})$, ), 7.47-7.51 (m, $\left.2 \mathrm{H}, \mathrm{ArH}\right)$; Anal. Calcd. for $\mathrm{C}_{19} \mathrm{H}_{18} \mathrm{O}_{3}: \mathrm{C}, 77.53 ; \mathrm{H}, 6.16$. Found: $\mathrm{C}, 77.70 ; \mathrm{H}, 6.25$.

\section{3,4,6,7-Tetrahydro-9-(2-methoxyphenyl)-2H-xanthene-1,8(5H,9H)-dione (4c)}

White solid; $\mathrm{mp} 233-235^{\circ} \mathrm{C} ;{ }^{1} \mathrm{H}$ NMR (DMSO- $\left.d_{6}, 300 \mathrm{MHz}\right) \delta 1.85-2.01\left(\mathrm{~m}, 4 \mathrm{H}, \mathrm{CH}_{2}\right), 2.22-2.32(\mathrm{~m}$, $\left.4 \mathrm{H}, \mathrm{CH}_{2}\right), 2.34-2.64\left(\mathrm{~m}, 4 \mathrm{H}, \mathrm{CH}_{2}\right), 3.69\left(\mathrm{~s}, 3 \mathrm{H}, \mathrm{CH}_{3}\right), 4.41(\mathrm{~s}, 1 \mathrm{H}, \mathrm{CH}), 6.60-6.71(\mathrm{~m}, 2 \mathrm{H}, \mathrm{ArH})$, ), 6.72-6.74 (m, 1H, ArH), 6.75-6.78 (m, 1H, ArH); Anal. Calcd. for $\mathrm{C}_{20} \mathrm{H}_{20} \mathrm{O}_{4}: \mathrm{C}, 74.06 ; \mathrm{H}, 6.21$. Found: $\mathrm{C}, 74.25 ; \mathrm{H}, 6.29$.

\section{3,4,6,7-Tetrahydro-9-(2-hydroxyphenyl)-2H-xanthene-1,8(5H,9H)-dione (4e)}

White solid; mp 220-222 ${ }^{\circ} \mathrm{C} ;{ }^{1} \mathrm{H}$ NMR (DMSO- $\left.d_{6}, 300 \mathrm{MHz}\right) \delta 1.84-1.90\left(\mathrm{~m}, 4 \mathrm{H}, \mathrm{CH}_{2}\right), 2.10-2.20(\mathrm{~m}$, $\left.4 \mathrm{H}, \mathrm{CH}_{2}\right), 2.35-2.52\left(\mathrm{~m}, 4 \mathrm{H}, \mathrm{CH}_{2}\right), 3.89(\mathrm{~s}, 1 \mathrm{H}, \mathrm{CH}), 6.90-7.02(\mathrm{~m}, 1 \mathrm{H}, \mathrm{ArH}), 7.04-7.20(\mathrm{~m}, 3 \mathrm{H}, \mathrm{ArH}), 10.65$ (br, $1 \mathrm{H}, \mathrm{OH}$ ) ${ }^{13} \mathrm{C}$ NMR (DMSO- $d_{6}, 75 \mathrm{MHz}$ ) ): $\delta 20.3,26.9,31.1,36.8,55.2111 .3,114.8,115.8,120.6,129.4$, 146.4, 159.3, 165.3, 196.7 ppm; Anal. Calcd. for $\mathrm{C}_{19} \mathrm{H}_{18} \mathrm{O}_{4}$ : C, 73.53; H, 5.85. Found: C, 73.34; H, 5.77.

\section{3,4,6,7-Tetrahydro-9-(3-hydroxy-4-methoxyphenyl)-2H-xanthene-1,8(5H,9H)-dione (4f)}

White solid; mp 190-192 ${ }^{\circ} \mathrm{C} ;{ }^{1} \mathrm{H}$ NMR (DMSO- $\left.d_{6}, 300 \mathrm{MHz}\right) \delta 1.93-2.07\left(\mathrm{~m}, 4 \mathrm{H}, \mathrm{CH}_{2}\right), 2.32-2.38(\mathrm{~m}$, $\left.4 \mathrm{H}, \mathrm{CH}_{2}\right), 2.52-2.59\left(\mathrm{~m}, 4 \mathrm{H}, \mathrm{CH}_{2}\right), 3.83\left(\mathrm{~s}, 3 \mathrm{H}, \mathrm{CH}_{3}\right), 4.67(\mathrm{~s}, 1 \mathrm{H}, \mathrm{CH}), 6.70(\mathrm{~d}, 1 \mathrm{H}, J=8.1 \mathrm{~Hz}, \mathrm{ArH}), 6.79(\mathrm{~d}$, $1 \mathrm{H}, J=8.1 \mathrm{~Hz}, \mathrm{ArH}), 6.80-6.90(\mathrm{~m}, 1 \mathrm{H}, \mathrm{ArH}), 8.82(\mathrm{~s}, 1 \mathrm{H}, \mathrm{OH}) ;{ }^{13} \mathrm{C}$ NMR (DMSO- $\left.d_{6}, 75 \mathrm{MHz}\right)$ ): $\delta 20.3,26.9$, 30.2, 36.9, 56.0, 112.4,116.0, 116.3, 118.8, 137.7, 146.3, 146.4, 164.9, 196.8 ppm; Anal. Calcd. for $\mathrm{C}_{20} \mathrm{H}_{20} \mathrm{O}_{5}$ : C, 70.57; H, 5.92. Found: C, 70.39; H, 5.99.

\section{3,4,6,7-Tetrahydro-9-(2-hydroxynaphthalen-1-yl)-2H-xanthene-1,8(5H,9H)-dione (4g)}

White solid; mp 295-297 ${ }^{\circ} \mathrm{C} ;{ }^{1} \mathrm{H}$ NMR (DMSO- $\left.d_{6}, 300 \mathrm{MHz}\right) \delta 1.59-1.63\left(\mathrm{t}, 2 \mathrm{H}, J=5.7 \mathrm{~Hz}, \mathrm{CH}_{2}\right.$ ), $1.84-$ $2.03\left(\mathrm{~m}, 2 \mathrm{H}, \mathrm{CH}_{2}\right), 2.10-2.23\left(\mathrm{~m}, 6 \mathrm{H}, \mathrm{CH}_{2}\right), 2.64-2.65\left(\mathrm{~m}, 2 \mathrm{H}, \mathrm{CH}_{2}\right), 5.60(\mathrm{~s}, 1 \mathrm{H}, \mathrm{CH}), 7.23(\mathrm{~d}, 1 \mathrm{H}, J=8.7 \mathrm{~Hz}$, ArH), 7.37-7.39 ( m, 2H, ArH), 7.75 ( d, $1 \mathrm{H}, J=9.0 \mathrm{~Hz}, \mathrm{ArH}), 7.84-7.86$ ( d, $1 \mathrm{H}, J=7.8 \mathrm{~Hz}, \mathrm{ArH}), 8.19$ (d, $1 \mathrm{H}$, $J=8.4 \mathrm{~Hz}, \mathrm{ArH}$ ), 10.75 (s, $1 \mathrm{H}, \mathrm{OH}) ;{ }^{13} \mathrm{C}$ NMR (DMSO- $\left.d_{6}, 75 \mathrm{MHz}\right) \delta 20.7,20.8,24.1,27.5,37.3,112.4,117.1$, 117.7, 124.0, 124.7, 126.9, 128.1, 128.7, 131, 132, 148.5, 166.7, 196.6 ppm; Anal. Calcd. for $\mathrm{C}_{23} \mathrm{H}_{20} \mathrm{O}_{4}: \mathrm{C}$, 76.65; H, 5.59. Found: C, 76.84; H, 5.47.

\section{3,4,6,7-Tetrahydro-9-(4-chlorophenyl)-2H-xanthene-1,8(5H,9H)-dione (4h)}

White solid; mp 229-231 ${ }^{\circ} \mathrm{C} ;{ }^{1} \mathrm{H}$ NMR $\left(\mathrm{CDCl}_{3}, 300 \mathrm{MHz}\right) \delta 1.80--2.01\left(\mathrm{~m}, 4 \mathrm{H}, \mathrm{CH}_{2}\right), 2.24-2.29(\mathrm{~m}$, $\left.4 \mathrm{H}, \mathrm{CH}_{2}\right), 2.43-2.53\left(\mathrm{~m}, 4 \mathrm{H}, \mathrm{CH}_{2}\right), 4.68(\mathrm{~s}, 1 \mathrm{H}, \mathrm{CH}), 7.30(\mathrm{~d}, 1 \mathrm{H}, J=8.1 \mathrm{~Hz}, \mathrm{ArH}), 7.42(\mathrm{~d}, 1 \mathrm{H}, J=8.1 \mathrm{~Hz}$, ArH); Anal. Calcd. for $\mathrm{C}_{19} \mathrm{H}_{17} \mathrm{ClO}_{3} \mathrm{C}, 69.41 ; \mathrm{H}, 5.21$. Found: C, 69.57; H, 5.29.

\section{3,4,6,7-Tetrahydro-9-(4-flourophenyl)-2H-xanthene-1,8(5H,9H)-dione (4j)}

White solid; mp 268-270 ${ }^{\circ} \mathrm{C} ;{ }^{1} \mathrm{H}$ NMR (DMSO- $\left.d_{6}, 300 \mathrm{MHz}\right) \delta 1.89-2.01\left(\mathrm{~m}, 4 \mathrm{H}, \mathrm{CH}_{2}\right), 2.16-2.35(\mathrm{~m}$, $\left.4 \mathrm{H}, \mathrm{CH}_{2}\right), 2.47-2.62\left(\mathrm{~m}, 4 \mathrm{H}, \mathrm{CH}_{2}\right), 5.22(\mathrm{~s}, 1 \mathrm{H}, \mathrm{CH}), 7.24(\mathrm{t}, 1 \mathrm{H}, J=8.1 \mathrm{~Hz}, \mathrm{ArH}), 7.33(\mathrm{~d}, 1 \mathrm{H}, J=7.5 \mathrm{~Hz}$, $\mathrm{ArH}), 7.44(\mathrm{~d}, 1 \mathrm{H}, J=7.5 \mathrm{~Hz}, \mathrm{ArH}), \mathrm{C}_{19} \mathrm{H}_{17} \mathrm{FO}_{3} \mathrm{C}, 73.06 ; \mathrm{H}, 5.49$. Found: C, 73.25; H, 5.38. 


\section{3,4,6,7-Tetrahydro-9-(2-hydroxynaphthalen-1-yl)-3,3,6,6-tetramethyl-2H-xanthene- 1,8(5H,9H)-dione (4n)}

White solid; mp 272-274 ${ }^{\circ} \mathrm{C} ;{ }^{1} \mathrm{H}$ NMR (DMSO- $\left.d_{6}, 300 \mathrm{MHz}\right) \delta 0.81$ (s, $\left.6 \mathrm{H}, \mathrm{CH}_{3}\right), 0.99\left(\mathrm{~s}, 3 \mathrm{H}, \mathrm{CH}_{3}\right.$ ), 1.08 (s, $\left.3 \mathrm{H}, \mathrm{CH}_{3}\right), 2.05-2.38\left(\mathrm{~m}, 5 \mathrm{H}, \mathrm{CH}_{2}\right), 2.44-2.68\left(\mathrm{~m}, 3 \mathrm{H}, \mathrm{CH}_{2}\right), 5.60(\mathrm{~s}, 1 \mathrm{H}, \mathrm{CH}), 7.22(\mathrm{~d}, 1 \mathrm{H}, J=8.7 \mathrm{~Hz}$, ArH), 7.37-7.47 (m, 2H, ArH), $7.75(\mathrm{~d}, 1 \mathrm{H}, J=8.7 \mathrm{~Hz}, \mathrm{ArH}), 7.83(\mathrm{t}, 1 \mathrm{H}, J=1.5 \mathrm{~Hz}, \mathrm{ArH}), 8.21(\mathrm{~d}, 1 \mathrm{H}, J=$ $8.1 \mathrm{~Hz}, \mathrm{ArH}), 10.51(\mathrm{~s}, 1 \mathrm{H}, \mathrm{OH}) ;{ }^{13} \mathrm{C}$ NMR (DMSO- $\left.d_{6}, 75 \mathrm{MHz}\right) \delta 23.8,26.3,27.9,29.8,31.9,32.2,43.7,51.0$, 111.1, 117.1, 117.8, 124.1, 124.7, 126.8, 128.1, 128.6, 131, 132, 148.5, 164.8, 196.3 ppm; Anal. Calcd. for $\mathrm{C}_{27} \mathrm{H}_{28} \mathrm{O}_{4}$ : C, 77.86; H, 6.78. Found: C, 77.67; H, 6.87.

\section{Results and discussion}

At the beginning of this work, the reaction of 1,3-cyclohexanedione 1a $(2 \mathrm{mmol})$ with benzaldehyde $2 a(1 \mathrm{mmol})$ was chosen as a model reaction at $50^{\circ} \mathrm{C}$ in several solvents including toluene, $\mathrm{CH}_{3} \mathrm{CN}, 1$,4-dioxane, DCM, DMF, THF, EtOH, MeOH, and $\mathrm{H}_{2} \mathrm{O}$ (Table 1). As it could be seen in this table, only the open-chain compound 3a was obtained as the product. When the reaction was carried out in the water at 70 and $90{ }^{\circ} \mathrm{C}$, only the product 3a was obtained, and the cyclized product $4 \mathbf{a}$ was not formed (Table 1, entries 10 and 11).

Table 1. Effects of different solvents on reaction of benzaldehyde with 1,3-cyclohexanedione. ${ }^{\mathrm{a}}$<smiles>O=C1CCCC(=O)C1</smiles>

\begin{tabular}{|c|c|c|c|}
\hline \multirow[t]{2}{*}{ Entry } & \multirow[t]{2}{*}{ Solvent } & \multicolumn{2}{|c|}{ Yield $(\%)^{b}$} \\
\hline & & Product 3a & Product 4a \\
\hline 1 & Toluene & \multicolumn{2}{|c|}{ Trace } \\
\hline 2 & $\mathrm{CH}_{3} \mathrm{CN}$ & 10 & --- \\
\hline 3 & 1,4-Dioxane & 10 & --- \\
\hline 4 & DCM & 40 & --- \\
\hline 5 & DMF & 40 & --- \\
\hline 6 & THF & 25 & $\begin{array}{ll}-- \\
\end{array}$ \\
\hline 7 & $\mathrm{EtOH}$ & 15 & --- \\
\hline 8 & $\mathrm{MeOH}$ & 10 & --- \\
\hline 9 & $\mathrm{H}_{2} \mathrm{O}$ & 60 & --- \\
\hline $10^{c}$ & $\mathrm{H}_{2} \mathrm{O}$ & 78 & --- \\
\hline $11^{\mathrm{d}}$ & $\mathrm{H}_{2} \mathrm{O}$ & 90 & --- \\
\hline
\end{tabular}

aneaction conditions: 1,3-cyclohexanedione 1a, $2.0 \mathrm{mmol}$; benzaldehyde $\mathbf{2 a}, 1.0 \mathrm{mmol}$; solvent, $3 \mathrm{~mL}$; temperature, $50{ }^{\circ} \mathrm{C}$; for $2 \mathrm{~h}$. ${ }^{\mathrm{b}}$ Isolated yield. ${ }^{\mathrm{c}}$ Reaction at $70{ }^{\circ} \mathrm{C}$. ${ }^{\mathrm{d}}$ Reaction at $90{ }^{\circ} \mathrm{C}$.

Then we attempted to optimize the reaction conditions using the magnetized solvents in order to improve the yield of the target product $4 \mathbf{a}$.

The magnetized solvents were prepared using a static magnetic system of $0.8 T$ field strength (Fig. 1). The solvent $(5 \mathrm{~mL})$ was put in a test tube, which was then put in a magnetic field for $20 \mathrm{~min}$. The tube was subsequently removed from the instrument and used for the reaction. 


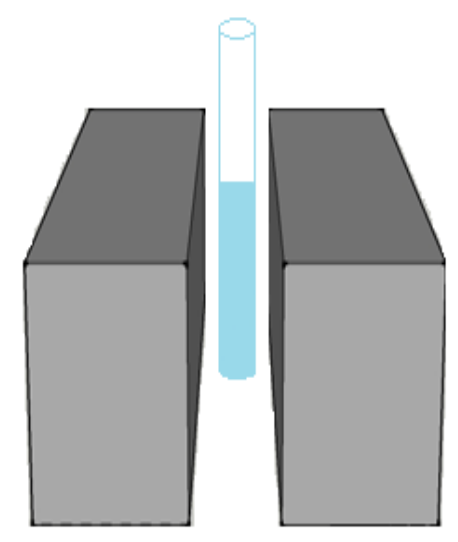

Fig. 1. The pilot for solvent magnetization apparatus.

Similarly, the above model reaction was carried out in the magnetized solvents with a magnetization time $20 \mathrm{~min}$. As indicated in Table 2, the target product 4a was not formed in the non-polar and polar magnetized solvents (Table 2, entries 1-6), and even magnetized ethanol and magnetized methanol, as the polar protic solvents, were unable to produce the desired product $\mathbf{4 a}$ in an acceptable yield (Table 2, entries 7 and 8). Surprisingly, the cyclized product $4 \mathbf{a}$ was obtained in a $75 \%$ yield within the same time $(2 \mathrm{~h})$ when magnetized water was used as the solvent (Table 2, entry 9). It seems that magnetized water is a suitable solvent with respect to the reaction yield for $\mathbf{4 a}$.

Table 2. The effect of different magnetized solvents on the synthesis of $\mathbf{4 a}{ }^{a}{ }^{a}$

\begin{tabular}{|c|c|c|c|}
\hline \multirow[t]{2}{*}{ Entry } & \multirow[t]{2}{*}{ Magnetized solvent } & \multicolumn{2}{|c|}{ Yield (\%) } \\
\hline & & Product 3a & Product 4a \\
\hline 1 & Toluene & \multicolumn{2}{|c|}{10} \\
\hline 2 & $\mathrm{CH}_{3} \mathrm{CN}$ & 40 & --- \\
\hline 3 & 1,4-Dioxane & 30 & --- \\
\hline 4 & $\mathrm{DCM}$ & 50 & --- \\
\hline 5 & DMF & 50 & --- \\
\hline 6 & THF & 30 & --- \\
\hline 7 & EtOH & 40 & 17 \\
\hline 8 & $\mathrm{MeOH}$ & 30 & 25 \\
\hline 9 & $\mathrm{H}_{2} \mathrm{O}$ & 25 & 75 \\
\hline
\end{tabular}

aReaction conditions: 1,3-cyclohexanedione 1a, $2.0 \mathrm{mmol}$; benzaldehyde 2a, 1.0 mmol; solvent, $3 \mathrm{~mL}$; magnetization time, $20 \mathrm{~min}$; temperature, $50{ }^{\circ} \mathrm{C}$; for $2 \mathrm{~h}$. ${ }^{b}$ Isolated yield.

Thus to optimize the reaction conditions, the above model reaction was carried out in magnetized water under different reaction conditions. As shown in Table 3, it seems that the water magnetization time plays an important role in achieving a high-yield product 4a. An increase in the water magnetization time up to 20 min led to a high reaction yield ( $75 \%$ ) (Table 3 , entry 4 ). Also in the optimization process, the role of temperature was investigated (Table 3, entries 5-7). We find that $90{ }^{\circ} \mathrm{C}$ gives the best result (Table 3, entry 7). 
Table 3. Synthesis of 3,4,6,7-tetrahydro-9-phenyl-2H-xanthene-1,8-dione 4a in magnetized water under

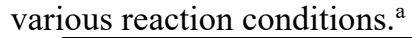

\begin{tabular}{|c|c|c|c|c|}
\hline Entry & Magnetization time (min) & Temp. $\left({ }^{\mathbf{0}} \mathbf{C}\right)$ & Reaction time (min) & Yield (\%) $^{\mathbf{b}}$ \\
\hline 1 & 5 & 50 & 120 & 50 \\
\hline 2 & 10 & 50 & 120 & 57 \\
\hline 3 & 15 & 50 & 120 & 68 \\
\hline 4 & 20 & 50 & 120 & 75 \\
\hline 5 & 30 & 50 & 120 & 73 \\
\hline 6 & 20 & 70 & 60 & 89 \\
\hline 7 & $\mathbf{2 0}$ & $\mathbf{9 0}$ & $\mathbf{2 0}$ & $\mathbf{9 8}$ \\
\hline 8 & 20 & 90 & 30 & 96 \\
\hline
\end{tabular}

aReaction conditions: 1,3-cyclohexanedione 1a, $2.0 \mathrm{mmol}$; benzaldehyde 2a, $1.0 \mathrm{mmol}$; magnetized water, $3 \mathrm{~mL}$. 'Isolated yield.

One should pay attention to this fact that the synthesis of xanthenes is generally carried out in the presence of acids, bases or a metal-containing catalysts with the assistance of organic solvents or ionic liquids. [9-15] Clearly, the preparation via these reported methods not only leaves behind a lot of organic or inorganic wastes during the work-up procedure but also is bothered with the problem of carrying away trace amounts of the residual metal species from the desired compound when it is utilized in pharmaceutical synthesis. Performing the model reaction in magnetized water not only gives a high reaction yield but also keeps away the (i) production of detrimental wastes, (ii) use of a large amount of catalyst or organic solvent, and (iii) tedious post-treatment. Therefore, in our opinion, our developed system is an interesting protocol for the preparation of the target product from the viewpoint of green synthesis.

To illustrate the versatility of this method, a series of aromatic aldehydes were studied under the standardized reaction conditions, and the results obtained were tabulated in Table 4. A broad scope of different aldehydes containing electron-donating or electron-withdrawing substituents was tested, and 1,8dioxooctahydroxanthenes were obtained in good to excellent yields. The nature of the functional group present on the aromatic ring of the aldehyde used exerted a slight influence on the reaction time. Furthermore, the steric effects of the substituents of the aromatic aldehydes had no obvious impact on the reaction yield.

Table 4. Synthesis of 1,8-dioxooctahydroxanthenes 4.a

Catalyst-free
Additive-free




\begin{tabular}{|c|c|c|c|c|c|c|}
\hline 13 & $\mathrm{H}$ & $4-\mathrm{NO}_{2}-\mathrm{C}_{6} \mathrm{H}_{4}-$ & 57 & $\mathbf{4 k}$ & 97 & $227-229(230-232)[27]$ \\
\hline 14 & $\mathrm{Me}$ & $\mathrm{Ph}$ & 20 & $\mathbf{4 l}$ & 95 & $198-200(202-204)[9]$ \\
\hline 15 & $\mathrm{Me}$ & $4-\mathrm{MeO}-\mathrm{C}_{6} \mathrm{H}_{4-}$ & 68 & $\mathbf{4 m}$ & 90 & $235-237(239-240)[29]$ \\
\hline 16 & $\mathrm{Me}$ & $2-\mathrm{OH}-\mathrm{C}_{10} \mathrm{H}_{6-}$ & 90 & $\mathbf{4 n}$ & 83 & $272-274$ \\
\hline 17 & $\mathrm{Me}$ & $2-\mathrm{Cl}-\mathrm{C}_{6} \mathrm{H}_{4}$ & 86 & $\mathbf{4 o}$ & 75 & $217-219(220-235)[9]$ \\
\hline 18 & $\mathrm{Me}$ & $4-\mathrm{Cl}_{6} \mathrm{C}_{6} \mathrm{H}_{4}$ & 90 & $\mathbf{4 p}$ & 70 & $228-230(227-229)[29]$ \\
\hline 19 & $\mathrm{Me}$ & $2-\mathrm{F}_{6} \mathrm{C}_{6} \mathrm{H}_{4-}$ & 82 & $\mathbf{4 q}$ & 80 & $227-229(230-235)[30]$ \\
\hline 20 & $\mathrm{Me}$ & $4-\mathrm{NO}_{2}-\mathrm{C}_{6} \mathrm{H}_{4-}$ & 80 & $\mathbf{4 r}$ & 99 & $226-228(230-232)[31]$ \\
\hline
\end{tabular}

${ }^{a}$ Reaction conditions: 1,3-cyclohexanedione or dimedone $(2.0 \mathrm{mmol})$, an aldehyde $(1.0 \mathrm{mmol})$, magnetization time (20 min), magnetized water $(3 \mathrm{~mL}), 90^{\circ} \mathrm{C}$. ${ }^{\mathrm{b}}$ Isolated yield.

Toledo et al. [32], have proved the effect of an external magnetic field on the physical and chemical properties of water through an experimental and a theoretical procedure. They have pointed out the existence of a competition between the intra- and inter-molecular hydrogen bond networks in water, which weakens the stronger intra-cluster hydrogen bonds, breaks the larger clusters, and forms the smaller ones with stronger intercluster hydrogen bonds. Therefore, the number of hydrogen bonds between the magnetized water molecules and the reacting molecules increases. In addition, very recently, we described the synthesis of tetrahydro-benzo $[b]$ pyrans from the reaction of 1,3-cyclohexanedione/dimedone, aldehydes and malononitrile in magnetized water as a solvent.[23] Based on the obtained results, we proved that the magnetized water causes more attractive forces between the aldehydes and 1,3-cyclohexanedione molecules and, hence, enhances the interactions between them, leading to an increase in the reaction rate and chemical reactivity at the molecular level. Also, magnetized water of specific diffusion and viscosity can excite new hydrogen bondings in the reactants. Thus we believe that the hydrogen bonds between molecules of magnetized water and molecules of the substrates and intermediates involved in a reaction are responsible for the reaction activation.

Mechanistically, 1,3-cyclohexanedione I was converted to its corresponding enolate form II in the presence of magnetized water. Magnetized water plays a major role in its promoting activity for the formation of compound III, which is readily prepared in situ by the Knoevenagel condensation of benzaldehyde 2a with enolate form II. Finally, the Michael-type addition of the enolate form II to compound III followed by cyclization and tautomerization yielded 3,4,6,7-tetrahydro-9-phenyl-2H-xanthene-1,8(5H,9H)-dione 4a (Scheme 2).

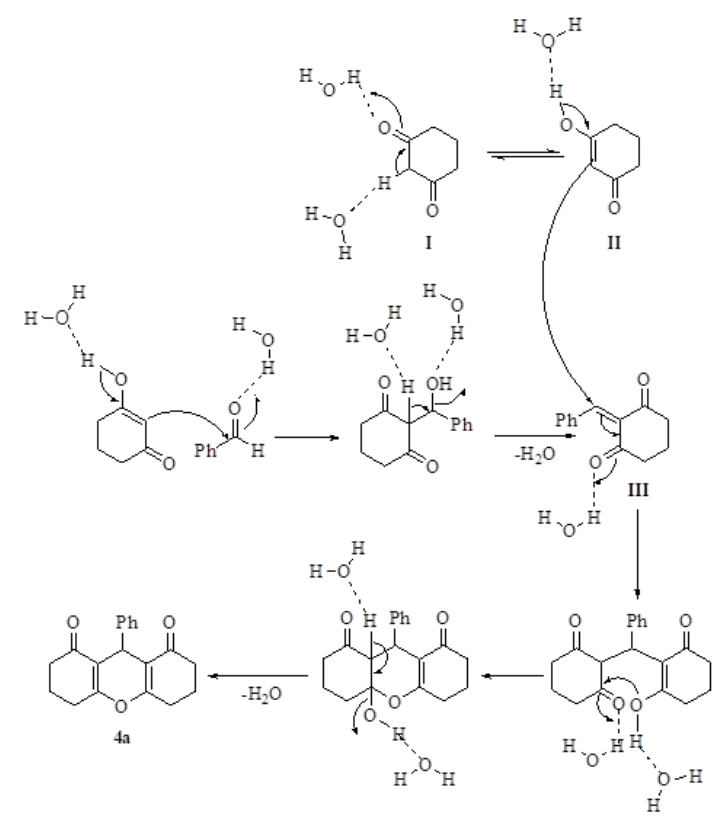

Scheme 2. A plausible mechanism for synthesis of 1,8-dioxooctahydroxanthene $\mathbf{4 a}$. 
A comparative study of the reaction conditions for the synthesis of 1,8-dioxooctahydroxanthene 41 using the methods given in Table 5 in the present letter demonstrates that the proposed protocol is actually better than several other ones. Most of the listed methodologies suffer from some limitations such as the use of catalysts, long reaction times, harsh reactions, and the use of organic solvents. As shown in Table 5, the synthesis of 1,8-dioxooctahydroxanthene 41 was performed in the presence of catalysts (Table 5, entries 1-11), while in the present protocol, 1,8-dioxooctahydroxanthene 41 was synthesized in the absence of catalysts or additives at $90^{\circ} \mathrm{C}$ in magnetized water (Table 5, entry 12).

Table 5. Comparison of our results with previously reported data for the synthesis of 41 .

\begin{tabular}{|c|c|c|c|c|}
\hline Entry & Catalyst & Reaction conditions & Time & $\begin{array}{l}\text { Yield (\%) } \\
\text { [ref.] }\end{array}$ \\
\hline 1 & Nano- $\mathrm{WO}_{3}-\mathrm{SO}_{3} \mathrm{H}$ & Solvent-free, $100^{\circ} \mathrm{C}$ & $70 \mathrm{~min}$ & $92[33]$ \\
\hline 2 & NSPVPC & Solvent-free, $100^{\circ} \mathrm{C}$ & $10 \mathrm{~min}$ & 98 [34] \\
\hline 3 & $\beta$-CD-BSA & $\mathrm{H}_{2} \mathrm{O}$, Reflux & $30 \mathrm{~min}$ & $93[35]$ \\
\hline 4 & MSA & Solvent-free, $100{ }^{\circ} \mathrm{C}$ & $60 \mathrm{~min}$ & $96[36]$ \\
\hline 5 & $\mathrm{Y}\left(\mathrm{NO}_{2}\right)_{3} .6 \mathrm{H}_{2} \mathrm{O}$ & $\mathrm{H}_{2} \mathrm{O}, 100{ }^{\circ} \mathrm{C}$ & $30 \mathrm{~min}$ & 96 [37] \\
\hline 6 & Starch sulfate & Solvent-free, $100^{\circ} \mathrm{C}$ & $18 \mathrm{~min}$ & 89 [38] \\
\hline 7 & $\begin{array}{lr}\text { 1,3-disulfonic } & \text { acid } \\
\text { imidazolium } & \text { hydrogen } \\
\text { sulfate } & \end{array}$ & Solvent-free, $55^{\circ} \mathrm{C}$ & $3 \mathrm{~min}$ & 94 [39] \\
\hline 8 & $\mathrm{PVPP}_{-\mathrm{BF}_{3}}$ & $\mathrm{CH}_{3} \mathrm{CN}, \mathrm{RT}$ & $4 \mathrm{~h}$ & $94[40]$ \\
\hline 9 & $\mathrm{Fe}_{2} \mathrm{O}_{3} @ \mathrm{SiO}_{2}-\mathrm{PW}$ & $\mathrm{H}_{2} \mathrm{O}, 70^{\circ} \mathrm{C}$ & $25 \mathrm{~min}$ & $94[41]$ \\
\hline 10 & Acetic acid & Solvent-free, $80^{\circ} \mathrm{C}$ & $5 \mathrm{~min}$ & $95[42]$ \\
\hline 11 & $\mathrm{CaCl}_{2}$ & $\mathrm{DMSO}, 85^{\circ} \mathrm{C}$ & $4 \mathrm{~h}$ & 85 [42] \\
\hline 12 & Catalyst-free & Magnetized water, $90^{\circ} \mathrm{C}$ & $20 \mathrm{~min}$ & 98 [This work] \\
\hline
\end{tabular}

\section{Conclusion}

We developed a catalyst-free, highly efficient, green, and one-pot protocol for the synthesis of 1,8dioxooctahydroxanthenes using magnetized water as a new solvent. This new process provides an opportunity to use magnetized water and avoids the use of environmentally harmful conventional organic solvents, wide scope of substrates, high reaction yield, short reaction time, cleaner reaction profile, easy work-up, and reduced waste production by the lack of a catalyst or an additive agent.

\section{Acknowledgment}

We gratefully acknowledge the financial support of the Research Council of the Shahrood University of Technology. Also, the authors declare no conflicts of interest.

\section{References}

1. Wan, Y.; Zhang, X. X.; Wang, C.; Zhao, L. L.; Chen, L. F.; Liu, G. X.; Huang, S. Y.; Yue, S. N.; Zhang, W. L.; Wu, H. Tetrahedron 2013, 13, 3947-3950.

2. Jamison, J. M.; Krabill, K.; Hatwalkar, A.; Jamison, E.; Tsai, C. C. Cell biology international reports 1990, 1, 1075-1084.

3. Rewcastle, G. W.; Atwell, G. J.; Zhuang L.; Baguley, B. C.; Denny, W. A. J. Med. Chem. 1991, $11,217-222$. 
4. Mulakayala, N.; Murthy, P. V.; Rambabu, D.; Aeluri, M.; Adepu, R.; Krishna, G. R.; Reddy, C. M.; Prasad, K. R.; Chaitanya, M.; Kumar, C. S.; Rao, M. B. Bioorg. Med. Chem. Lett. 2012, 6, 2186-2191.

5. Srihari, P.; Mandal, S. S.; Reddy, J. S.; Rao, R. S.; Yadav, J. S. Chin. Chem. Lett. 2008, 7, $771-774$.

6. Callan, J. F.; de Silva, A. P.; Magri, D. C. Tetrahedron 2005, 6, 8551-8588.

7. Ahmad, M.; King, T. A.; Ko, D. K.; Cha, B. H.; Lee, J. J. Phys. D: Appl. Phys. 2002, 5, 1473-1476.

8. Das, B.; Thirupathi, P.; Reddy, K. R.; Ravikanth, B.; Nagarapu, L. Catal. Commun. 2007, 8, 535-538.

9. Maghsoodlou, M. T.; Habibi-Khorassani, S. M.; Shahkarami, Z.; Maleki, N.; Rostamizadeh, M. Chin. Chem. Lett. 2010, 6, 686-689.

10. Xia, J. J.; Zhang, K. H. Molecules 2012, 5, 5339-5345.

11. 11 Mokhtary, M.; Langroudi, S. A. Monatsh. Chem. 2014, 9, 1489-1494.

12. Hazeri, N.; Masoumnia, A.; Mghsoodlou, M. T.; Salahi, S.; Kangani, M.; Kianpour, S.; Kiaee, S.; Abonajmi, J. Res. Chem. Intermed. 2015, 7, 4123-4131.

13. Dadhania, A. N.; Patel, V. K.; Raval, D. K. Compt. Rend. Chim. 2012, 5, 378-383.

14. Venkatesan, K.; Pujari, S. S.; Srinivasan, K. V. Synth. Commun. 2008, 2, 228-241.

15. Ball. P. A Bibliography of Water. Phoenix Press, 2000, 9, 373-387.

16. Pang, X. F. Chin. J. Atom. Mol. Phys. 2006, 7, 1-3.

17. Pang, X. F. Eur. Phys. J. B. 2006, 1, 5-23.

18. 18 Grewal, H. S.; Maheshwari, B. L. Bioelectromagnetics 2011, 1, 58-65.

19. Pang, X. F.; Deng, B.; Tang, B. Mod. Phys. Lett. B. 2012, 11, 1250-1269.

20. Chang, K. T.; Weng, C. I. J. Appl. Phys. 2006, 4, 043917.

21. Guo, Y. Z.; Yin, D. C.; Cao, H. L.; Shi, J. Y.; Zhang, C. Y.; Liu, Y. M.; Huang, H. H.; Liu, Y.; Wang, Y.; Guo, W. H.; Qian, A. RInt. J. Mol. Sci. 2012, 12, 16916-16928.

22. Baran, B.; Berezyuk, O.; Golonzhka, V. Environ. Eng. Manag. J. 2006, 38, 19-23.

23. Gang, N.; St-Pierre, L.; Persinger, M. Water 2012, 3, 122-131.

24. Higashitani, K.; Oshitani, J.; Ohmura, N. Colloids Surf. A 1996, 109, 167-173.

25. Bakherad, M.; Keivanloo, A.; Gholizadeh, M.; Doosti, R.; Javanmardi, M. Res. Chem. Intermed. 2017, 43, 1013-1029.

26. Bakherad, M.; Moosavi, F.; Keivanloo, A.; Doosti, R.; Moradian, E.; Armaghan, M. Res. Chem. Intermed. 2019, 45, 2981-2997.

27. Bakherad, M.; Doosti, R.; Keivanloo, A.; Gholizadeh, M.; Jadidi, K. J. Iran. Chem. Soc. 2017, 14, 2591-2597.

28. Bakherad, M.; Doosti, R.; Keivanloo, A.; Gholizadeh, M.; Amin, A. H. Lett. Org. Chem. 2017, 14, 510-516.

29. Bakherad, M.; Moosavi, F.; Doosti, R.; Keivanloo, A.; Gholizadeh, M. New J. Chem. 2018, 42, 45594566.

30. John, A.; Yadav, P. J.; Palaniappan, S. J. Mol. Catal. A: Chem. 2006, 2, 121-125.

31. Pramanik, A.; Bhat, S. Catal. Commun. 2012, 5, 17-24.

32. Song, G.; Wang, B.; Luo, H.; Yang, L. Catal. Commun. 2007, 4, 673-676.

33. Dabiri, M.; Baghbanzadeh, M.; Arzroomchilar, E. Catal. Commun. 2008, 5, 939-942.

34. Mahdavinia, G. H. J. Iran. Chem. Res. 2008, 1, 11-17.

35. Toledo, E. J.; Ramalho, T. C.; Magriotis, Z. M. J. Mol. Struct. 2008, 888, 409-415.

36. Amoozadeh, A.; Rahmani, S. J. Mol. Catal. A: Chem. 2015, 3, 96-107.

37. Shirini, F.; Abedini, M.; Pourhasan, R. Dye. Pig. 2013, 4, 38581-38588.

38. Gong, K.; Wang, H.; Wang, S.; Wang, Y.; Chen, J. J. Catal. 2015, 8, 1249-1255.

39. Karami, B.; Zare, Z.; Eskandari, K. Chem. Pap. 2013, 2, 145-154.

40. Karami, B.; Eskandari, K.; Zare, Z.; Gholipour, S. Chem. Heterocycl. Comp. 2014, 12, 1715-1722.

41. Shaterian, H. R.; Rigi, F. Res. Chem. Intermed. 2015, 2, 721-738.

42. Shirini, F.; Yahyazadeh, A.; Mohammadi, K. Chin. Chem. Lett. 2014, 2, 341-347.

43. Mokhtary, M.; Langroudi, S. A. Monatsh. Chem. 2014, 9, 1489-1494.

44. Rafiee, E.; Eavani, S.; Khodayari, M. Chin. J. Catal. 2013, 8, 1513-1518.

45. Ilangovan, A.; Muralidharan, S.; Sakthivel, P.; Malayappasamy, S.; Karuppusamy, S.; Kaushik, M. P. Tetrahedron Lett. 2013, 6, 491-494. 